\title{
Correction to: trisected pancreas model for testing tissue dissociation enzyme combinations: a novel methodology for improving human islet yield for clinical islet transplantation
}

\author{
Gopalakrishnan Loganathan $^{1,2} \cdot$ Subhashree Venugopal ${ }^{2}$ - Appakalai N. Balamurugan ${ }^{1}$ \\ Published online: 8 February 2021 \\ (C) Springer Nature Switzerland AG 2021
}

Correction to: Journal of Diabetes \& Metabolic Disorders (2020) 19:381-389.

https://doi.org/10.1007/s40200-020-00519-y

The first-named author is affiliated to both institutions listed below.

The original online version of this article was revised.

Publisher's note Springer Nature remains neutral with regard to jurisdictional claims in published maps and institutional affiliations.

The online version of the original article can be found at https://doi.org/ 10.1007/s40200-020-00519-y

Subhashree Venugopal

vsubhashree@vit.ac.in

$\triangle$ Appakalai N. Balamurugan

bala.appakalai@louisville.edu

1 Department of Surgery, Clinical islet cell laboratory, Cardiovascular Innovation Institute, University of Louisville, Louisville, KY, USA

2 School of Biosciences and Technology, Vellore Institute of Technology, Vellore, India 